\title{
Teaching a Second Foreign Language in the Russian School
}

\author{
Alfia Gazizova ${ }^{1, *}$, Nailya Mingazova ${ }^{2}$, and Vitaly Subich $^{2}$ \\ ${ }^{1}$ Kazan National Research Technical University named after A.N. Tupolev - KAI, Russia, 420111, \\ Kazan, K.Marx St., 10 \\ ${ }^{2}$ Kazan Federal University, Russia, 420008, Kazan, Kremlevskaya str., 18
}

\begin{abstract}
Development of international cooperation which led to the inclusion of the second foreign language into the compulsory discipline list, according to the Federal Standards of Basic Education of the Russian Federation, raises the questions of radical changes, directions and conditions of teaching foreign languages which influence the formation of multilingual personality. The paper is aimed at looking into the peculiarities and problems of teaching a second foreign language in the Russian school in terms of goal-setting and the organization of educational process. The study is based on the experience of 22 schools in the Republic of Tatarstan, having been realized through investigating academic papers, official documents, contemplation of the educational process, etc. The results of the study reflect the organizational and methodological issues of foreign language teaching in the Republic (starting time of studying, duration of learning a foreign language, teaching staff, means of teaching, methodological basis, etc.) as well as the demand for learning European and oriental languages. The authors point out the relevance of better conditions for teaching a second foreign language (creating of organizational models, definition of the course length, etc.) and defining the objectives, connected with the contents of the academic discipline, efficiency of teaching a foreign language and the professional qualities of the teacher, his competence.
\end{abstract}

\section{Introduction}

\subsection{The problem of teaching a second foreign language in the Russian school}

Development of international cooperation and communication in the modern world leads to the necessity of a good command of a few foreign languages, basing on international requirements of the language competences, which logically actualizes the issues of qualitative transformations of the directions, approaches and conditions in foreign language teaching.

\footnotetext{
*Corresponding author: Alfgazva@mail.ru
} 
The growing interest to the problem in the Russian education system is caused by the definitions of what the second foreign language's status is (SFL). According to articles 11.1, 18.3.1. of the Federal State Educational Standard of Basic Education (FSESBE), SFL has been included in the list of subjects under the title "Philology" along with "Foreign Language". Dealing with its school curriculum, an educational body may include SFL into the plan as a compulsory subject starting from the $5^{\text {th }}$ grade in the event of the parents' request and the school's ability to provide necessary conditions. In general, it reflects real progress in the direction of polycultural education and formation of multilingual personality; the students develop linguistic faculties, verbal intellect, language reflexion, analytical thinking, memory, language intuition, other cognitive faculties. Bilingual competence is transformed into megalinguistic competence, which is characterized by the higher level of abstraction [1].

\subsection{Objectives and organization of SFL school teaching}

Analysis of official documents reveals that formulation of aims and objectives stated by the FSESBE of the second generation is of little difference from the first generation FSESBE. According to it, the main aim of the modern foreign language class is communicative competence which combines linguistic and sociocultural competences, giving birth to the personal active approach to the organization of the teaching process.

The English language, being the means of intercultural communication and the language of the community which has a significant economic and political influence in the world, is taught as the first foreign language (FFL). As for SFL, the students may choose between a Roman language (Spanish, French) and German, sometimes an oriental language such as Arabic, Turkic or Chinese, etc.

These relations between languages in favour of English exist in many world countries. At the same time there is a growing tendency to learn SFL. This tendency in the modern world is important since it reflects the real need in knowing foreign languages, other social cultures and types of political systems, that is why it develops the competences connected with intercultural communication. In such conditions, the problem of SFL teaching associated with the awareness of language material and linguistic peculiarities is gaining specific relevance, introducing significant changes to the language educational policy.

Introduction of SFL into the school should mean that the education is becoming multilingual: mother tongue, first foreign language and second foreign language combine to form the unique linguistic phenomenon, which is called artificial triglossia. According to N.V.Baryshnikov, [2], triglossia is characterized by imperfect command of two foreign languages with the communicative nature of triglossia being changed throughout FFL and SFL acquisition. Triglossia, the part of modern reality, compels to deal with the question of SFL teaching objectives not in isolation, but being aware of the existing trilingualism, which is, in fact, a daunting task as it is the objectives which influence the manner of all major components of the teaching process.

National pedagogical literature is represented by a relatively significant number of works in which attempts are made to state the aims and objectives of SFL school teaching (N.V. Baryshnikov, I.L. Bim, N.D. Galskova, L.G. Denisova, S.F. Shatilov, etc.). The definitions, offered by the scholars, reflect pragmatic, pedagogical aspects of teaching a foreign language and their sociocultural orientation as well as certain requirements to the level of students' competence within a wide variety of communicative activities. They are justified since they bear in mind the factor of linguistic experience adopted prior to the given stage, however they are not fully adequate owing to the fact that the experts do not pay attention to the difference in teaching the basic levels of FFL and SFL (in a variety of 
aspects), which, in fact, means that SFL should have its own basic level of communicative and other competences.

Another issue of paramount importance in teaching SFL is connected with the organization of the educational process. Taking in account the introduction and realization of FSESBE, this task is by no means an easy one; it is connected with a series of organizational and methodological problems, located both on theoretical and practical (even more relevant) levels alike, which are in need of being settled. To these may relate: which exactly SFL should be chosen for learning, what are the conditions of its instruction (availability of teaching staff, equipped classes, various means of teaching, etc.), the primary (and secondary) objectives and the core parameters for the course. The answers to these questions determine the design of the appropriate organizational models and methods of teaching.

\section{Purpose and methods}

The paper is aimed at looking into the peculiarities and problems of teaching a second foreign language in the Russian school in terms of goal-setting and the organization of educational process on the basis of works on the problems of SFL introduction into the Russian schools (V.A.Lapidus, N.V. Baryshnikov, N.D. Galskova, N.I. Ghez, L.N.Yakovleva, E.N.Solovtsova, L.B.Cheptsova and others), statistics, legal documents authorized by the Ministries of Science and Education of the Russian Federation and the Republic of Tatarstan, direct scrutiny over the educational process. The analysis of the organization peculiarities of teaching SFL has been conducted in 22 Tatarstan schools which are realizing the project comprising 2500 students: 6 schools with German as SFL, 6 schools with Turkic, 5 Chinese schools, 5 French schools, 2 English schools (FFL is either French or German), and 3 schools where the students are provided with Spanish, Arabic or Hebrew.

\section{Results}

The results of the investigation show that the conditions of SFL learning in the schools considered are by all means different. Starting points of learning SFL and course duration vary in relation to the type of school. Some of the schools start SFL teaching from the $6^{\text {th }}$ or $7^{\text {th }}$ grade (for the syllabi where FFL is learned from the $5^{\text {th }}$ grade) while other schools introduce SFL only in the senior school $\left(10^{\text {th }}-11^{\text {th }}\right.$ grades $)$; there are as well cases when SFL is introduced in the $2^{\text {nd }}$ or $3^{\text {rd }}$ grade as part of the extension group. More extended learning of SFL $\left(7^{\text {th }}-11^{\text {th }}\right.$ grades) is realized mainly in the 5 boarding lyceums (with the Turkic language) and one gymnasium which implemented teaching of the German language.

The demand for the second language learning in Tatarstan Republic is of two kinds: on the one hand, a preference for the European languages, and on the other hand, a desire for learning oriental languages, while noting the language parity. The interest in learning the languages of the world's most developed countries is explained by the desire of parents or students to follow their interests for mastering one of the European languages, which is considered to be prestigious. As for referring to the oriental languages in our republic, it is connected to social and economic peculiarities of the region, the priority international relationship with Asiatic countries, educational possibilities, in the sphere of professional education in particular (the existence of particular fields of study in Tatarstan educational institutions). Traditionally, Tatarstan Republic has close relations with Turkey, China, etc. There are a lot of joint enterprises, projects, and investment programmes. All these are reflected in the educational policy: the choice of learning an oriental language. 
The educational situation in a particular school is a significant factor while introducing a second language: availability/lack of relevant teaching aids, qualified FL pedagogical staff, their own FL teaching traditions. Moreover, "Foreign languages in the Republic of Tatarstan are mastered in the conditions of the parallel studying of the native languages Russian and Tatar. This should be taken into account when organizing the educational process to create the whole valuable language personality" [3].

Explaining to parents the preference for learning this or that foreign language in our region and in a particular school plays a major role [4, p.37]. It is obvious that parents should be informed of the educational services in FL teaching provided by the school (FFL or SFL, learning duration, FL learning results, further SFL learning perspectives while continuing studies in higher education, etc.). Informing parents of the achievements of the teachers speaking two FL and having a success in teaching FFL (their students take part in Olympiads and enter universities, etc.), presenting students' achievements in learning a particular FL and displaying students' choice of a language (artistic events) are of great importance and serve as the basis for introducing SFL in a particular school. It would be useful to inform parents that SFL learning process is much easier and more successful on the basis of mastered FFL. Intensive and successful training contributes to improving the educational process and students' motivation. FL 3 is being introduced in many European countries, with children acquiring it easily and parents supporting this idea enthusiastically.

There are certain problems in the republic in this field such as shortage or lack of qualified teaching staff. SFL choice is a difficult task for students because the teachers with two FL skills have changed the qualification or teach only English and do not want to develop SFL course due to some reasons. Issues relating to the teaching organization and conditions for different types of schools (such as the starting point of learning SFL, duration and intensity of training, total course hours, etc.) are not sufficiently developed. Lack of sufficient teaching methodology in secondary schools is among the main problems. There are no special textbooks for the full SFL learning course. Sometimes the textbooks for foreigners published in other countries and compiled according to the students' native language norms are used. Respectively, their FFL knowledge and skills that can be used while learning SFL and make FFL learning process much easier are not taken into consideration, as Titova points out in her research [5].

As Chiknaverova, Gazizova and Trofimova stated, "The first and second foreign language programs are similar in form and content, with the exception of hours allocated. Hence, some aspects under study remain outside curriculum. The differences also concern control and assessment as far as the time needed to complete a task, and the volume of teaching material" [6].

The peculiarities of SFL teaching (such as the later beginning of SFL learning, age factor, more restricted training time, etc.) that determine the setting of objectives, content and structure of the teaching methodology and the principles of students' educational process organization are not mostly taken into consideration. Among the positive results is the program "Arabic for the $5^{\text {th }}-11^{\text {th }}$ grade schoolchildren of secondary schools and gymnasiums" approved by the Republic of Tatarstan Ministry of Education and Science in 2010. On its basis the Arabic textbooks for the $5^{\text {th }}, 6^{\text {th }}, 7^{\text {th }}$ and $8^{\text {th }}$ grades have been published and introduced in the Republic of Tatarstan schools and in other regions of the Russian Federation [7]. As Subich, Mingazova, Zakirov and Al-foadi R.A. noted, "The improvement of Arabic teaching is achieved by the unification of the educational materials for secondary schools" [8]. 


\section{Discussion}

The data of the research reveals the necessity of improving SFL teaching organization conditions (such as defining organization models, learning hours, staff issues, etc.) and priority-setting that defines the selective content and effective methods of SFL teaching. According to the experts, FL teaching has to be based on learners' background linguistic and cultural knowledge and skills such as: implementing language training (individually or in pairs/groups); observing, comparing, contrasting, analyzing, arguing; recognizing linguistic phenomena and meaningful notions (international words, proper names, articles, sentence structure, auxiliary words and expressions, etc.); planning your speech, mastering listening skills, expressing your opinion; using the dictionary, guessing the meaning of new words in relation to word formation and context, extracting information [9].

The basic principles of effective SFL teaching methods in schools take into account the following:

a) positive transfer of knowledge and skills from the native language and FFL and interference prevention;

b) activation of learners' linguistic experience, acquired as a result of native and FFL learning;

c) learners' socio-cultural experience;

d) motivation to learning, contrasting new languages and cultures;

e) bipolar and tripolar comparison of languages and cultures;

f) the reflection of integration processes currently occurring in the international community in the teaching content;

g) systematic and consistent cross-discipline ties formation.

According to the abovementioned, SFL acquisition brings about two logical conditions - the interference problem and the possibility of positive transition. Interference, which occurs as the negative impact of the mother tongue and FFL on SFL, penetrates all the linguistic levels (phonetic, lexical, grammatical) but in a different way and cannot but influence the speech activity in SFL and non-verbal behavior [10].

Positive impact of the mother tongue on FFL and SFL is called positive transition or transference. "The transition in which the influencing language does not cause any norm violations in the language which is studied, but rather stimulates its features"[11] can take place on different levels:

- $\quad$ on the level of verbal cognitive activity: the more languages a person speaks, the more developed are his verbal cognitive skills: short-term memory, visual and audial perception, strategies of choosing language means, their combining, and production in speaking and writing;

- $\quad$ on language level: similar linguistic phenomena in the mother tongue and FFL are transferred by the learners into SFL and contribute to its acquisition;

- $\quad$ on the level of educational skills, which are developed when studying FFL;

- on sociocultural level: sociocultural knowledge, behavioral skills may be the objects of transference, especially in the case of similar European cultures.

As M.V. Shcherbakova stated [10], familiarization of learners with the language means of SFL requires contrastive approach, which assists in understanding similarities among languages (native, FFL, SFL) as well as discrepancies. Thus, it is of paramount importance to encourage learners to compare/contrast the language means of the languages in contact in all the cases when it will help prevent interference and initiate positive transition.

The effective usage of these approaches in SFL teaching is connected with teachers' professionalism, expertise, and qualification, including the ability to prepare for lessons, choose appropriate activities and materials basing on the planned result, analyze mistakes and shortcomings of the work done, communicate and interact with students, provide the 
educational support aimed at developing learners' independence, self-confidence and desire to be a success. Respectively, the key skill for FL teachers is the desire for selfdevelopment and self-improvement in the sphere of their subject activity and educational process organization $[12 ; 4]$.

Teachers' mega linguistic competence, including foreign language professional and communicative competence [13], that help them solve the existing tasks more effectively is of particular importance. Among the tasks are the following: to achieve the connection between extra linguistic content and formal structures of the language studied, foresee the interference, find the final ways of overcoming it and provide with the positive transfer of background knowledge and skills.

\section{Conclusion}

Currently, the introduction of SFL is a multiaspect and complex task which is connected with the definition of priority objectives of teaching SFL at a comprehensive school on the basis of which appropriate selection of practical syllabus, methods of teaching, and the organization of education (organizational models, duration of courses, teaching staff matters, etc.) are established.

Not all Russian schools, including our republic's, are ready to introduce second language teaching at the appropriate level and develop the basis for a step-by-step approach to the teaching process. So, further research and discussions of the problem analyzed at the round-table meetings, scientific-methodological and learning seminars are still up to date and in demand at the current stage of the education development.

\section{References}

1. L.V. Opolonetc. Nekotoryey osobennosti obucheniya vtoromu inostrannomu yazyku, Nauchno-metodicheskiy elecronniy zhurnal «Kontcept», V. 5, pp. 172-176. (2016). URL: http://e-koncept.ru/2016/56185.htm [Accessed 29 January 2018]

2. N.V. Baryshnikov Metodika obucheniya vtoromu inostrannomu yazyku v shkole, M.: Prosvescheniye, 159 p.( 2003)

3. N.G. Mingazova, V.G. Subich, R.R. Zakirov Mastering English as a second language via the parallels with the native language (using project work), Journal of Language and Literature, ISSN: 2078-0303, V. 7 (1), February, pp. 176-180. (2016)

4. Obucheniye angliyskomu yazyku v rossiyskikh shkolakh; Materialy IV vserosiyskogo seminara, Doklady I vystupleniya, Obninsk; Titul, 192 p. (2001).

5. O.A. Titova. Problemy obucheniya nemetckomu yazyku kak vtoromu inostrannomu v usloviyakh sovremennogo pedagogicheskogo vuza, Izvestiya Tulskogo gosudarstvennogo universiteta. Gumanitarniye nauki, V. 1, P. 172-176. (2008)

6. K. Chiknaverova, A. Gazizova, G.Trofimova G. The system of foreign language teaching at the master's level in Russia, New Trends and Issues Proceedings on Humanities and Social Sciences. [Online], 4(1), pp. 639-647. (2017). Available at: www.prosoc.eu

7. R.R. Zakirov, N.G. Mingazova. Mezhtcivilizatcionniy dialog v Respublike Tatarstan (na primere prepodavaniya arabskogo yazyka), Evraziyskiy juridicheskiy zhurnal, Vol. 2 (105), pp. 284-286. (2017)

8. V.G. Subich, N.G. Mingazova, R.R. Zakirov, R.A. Al-foadi. Improvement Strategies of Teaching the Arabic Language in The Tatarstan Schools, Modern Journal of Language Teaching Methods (MJLTM). Iran. (2017) 
9. N.S. Ivanova. Kulturovedcheskiy podhod k obucheniyu studentov yazykovogo vuza yaponskomu yazyku kak vtoromu inostrannomu: dissertatciya ... kandidata pedagogichrskikh nauk: 13.00.02 Sankt-Peterburg, 276 p. (2006)

10. M.V. Shcherbakova. Osobennosti obucheniya vtoromu inostrannomu yazyku studentov yazykovyh fakul'tetov, Vestnik VGU, Seriya lingvistika i mezhkul'turnaya kommunikaciya, Vol. 2., pp..84 -87. (2003)

11. L.V. Molchanova. Obuchenie vtoromu inostrannomu yazyku $\mathrm{v}$ usloviyah formirovaniya funkcional'nogo mnogoyazychiya $\mathrm{v}$ yazykovom vuze: avtoref. diss...kandidata pedagogicheskih nauk: 13.00.02 Ryazan. (2009)

12. N.D. Galskova, N.I. Gez. Teoriya obusheniya inostrannym yazykam. Lingvodidaktika I metodika: uchebnoyeposobiye, 5th edition, M: Izdatelskiy tcentr «Akademiya», 336 p. (2008).

13. V. Panfilova, A. Panfilov, A. Gazizova, N. Samarina. Professional and communicative foreign language competence of future teacher, SHS Web of Conferences [Online]. Vol. 37. International Congresses on Education 2017 (ERPA 2017), Budapest, Hungary, May 18-21, 2017. URL: https://www.shs-conferences.org/articles/ shsconf/abs/2017/05/contents/contents.html 